\title{
Informacje/Information
}

DOI : $10.14746 /$ pp.2020.25.2.13

\section{Profiles of International Relations in 2020 \\ Interview with Professor Robert Jervis at Columbia University in New York, November 15, 2019}

\section{Radoslaw Fiedler: What is the role of the U.S. during Trump's tenure - is it a stabilizer or troublemaker in international relations?}

Robert Jervis: The U.S. under Trump is playing both roles - of a stabilizer and troublemaker. Trump policy and politics are really very confusing and hard to understand. There is no clear direction and no coherent strategy. Additionally, we can observe some tensions inside Trump's administration. Usually, the bureaucratic structure embodies and represents American interests, and expresses continuity from one administration to the other. Another aspect is Trump's political appointees, national security advisors, cabinet secretaries and, occasionally, private ambassadors like Rudy Giuliani. But then there is the policy of the president himself who often calls for a different foreign policy. There should be an alignment, at least between the president and his political appointees, but there really isn't one on many issues. The president's appointees are much more hardline, especially in policy towards Russia, and they are worried about China and its geostrategic ambitions much more than its economic sense. They are much more willing to use force in the event of a tense crisis. The president, we have seen, wants to avoid military confrontations and he withdrew the military from the Middle East and Afghanistan. Trump wants to try to make a rapprochement with Russia and he tries to have a good political relation with China. The president regards China basically in economic terms but not necessarily in geopolitical terms. Before Trump, the president appointed the top advisors, because they wanted to have a spectrum of views and arguments in order to bring a difference to his decision-making. Averse to that approach, Trump does not like deliberations and meetings, which are boring in his opinion, and rarely digs deeply into the issues.

The last issue, there are ongoing debates about Trump's decision to withdraw from Northern Syria. The proponents and critics of the withdrawal are presenting contrary opinions. I certainly did not approve of his prompt decision. However, even if U.S. troops stay there, long-term stability is unlikely. Now, after the withdrawal, Kurds, Assad, and the Russians have come together and are making an agreement, which might be more stable than before.

\section{Is NATO in a bad condition - is this still a reliable alliance?}

Recently, the French President, Emanuel Macron, has said that NATO is brain-dead. In my opinion, this assertion is mostly exaggerated. Mark Twain once said: "the announcement of my death is premature." NATO is still alive with robust headquarters, with a lot of dedicated people from all of its member countries coordinating, sharing ideas, sharing information, and there is a lot of work being put in for the unity of the alliance. While Trump's demands for more spending in such a brute and undiplomatic manner have led to slightly increased European contributions, they have also undercut European political support for NATO. However, most of NATO's member states

${ }^{1}$ Interview made within the Bekker Program of the National Agency for Academic Exchange (NAWA). 
want the alliance to survive and are ready to participate more, not only in spending but also contributing to keeping the North Alliance in good condition.

\section{How should Trump policy towards China be understood?}

Is the trade imbalance the most important issue? The answer is not as obvious as it might seem. We need to consider at least three levels of U.S.-China relations: the trade imbalance, the stealing of American intellectual property, and Chinese regional ambitions and territorial tensions with its neighbors. Trump is mainly focused on the trade imbalance. What does imbalanced trade mean? Actually, it is partly an accounting trick. Because many goods, like iPhones, are assembled in China, their full value is counted as a Chinese export to the U.S. even though many of the goods and much of the work is done in other countries, like Vietnam. This means that the official trade imbalance with China is artificially inflated, although Trump probably does not understand this.

The second level of the dispute concerns Chinese industrial policy, stealing American intellectual property rights and strong-arming American corporations to make them provide technology transfers and information. The U.S. Secretary of the Treasury, Steven Mnuchin, is much more focused on this than Trump, who is looking for easy solutions with China. For Trump this means: buy more agricultural products or send us less.

The third level is more important for the American foreign policy elite, at least it has been in last twenty years; and this concerns China's activities towards its neighbors, the East China Sea and the South China Sea, disputes with Japan over Senkaku, and a dispute over another island - they built military bases there; for the administration this is important. For Trump it is less important and even his hawkish advisors said little about that. Most experts believe that Trump is chasing the wrong things.

\section{Why is Trump unable to improve relations with Russia?}

Trump really wants better relations with Russia, something Obama and Bush tried earlier, but they failed. The big debate is, why did they fail? The answer is American assertiveness and Russian expansion. Of course, Trump was inhibited by Congress passing sanction measures, which he didn't want to sign but he had to, because they were passed by a veto-proof majority. And he was inhibited because of political controversies over Russian interference in American politics, and Hillary Clinton saying that Trump is Russia's puppet. Trump is trying to overcome these measures. Every time he meets with President Vladimir Putin, he does incredible things like saying that he believes Putin than rather his intelligence service, Putin is really great, and "we can get on with him." But these statements don't advance the agenda of the Russian-America détente. He also did other things, like scrapping military arms control agreements, actions which make the relations with Russia much worse. In this incompetence and inconsistency, he strains relations more than he wants to. In fact, many IR scholars would like to improve relations with Russia even if it meant pushing Ukraine to make some concessions. But they are critical of Trump because he is unable to develop a clear and consistent policy. Taylor and Kent from the State Department, who favor a tougher policy on Russia, are very upset. For example, when the Ukrainian sailors and ship were captured, Trump did not do anything to resolve that crisis.

\section{How should the Russian actions in Ukraine be perceived?}

My own guess is that Putin is really an opportunist. People who think he is a great strategist are totally wrong. What Putin did in Donbas was a terrible mistake. The Ukrainian parliament's decision to remove Russian as an official language was provocative, and annexing the Crimea alone would have served his domestic needs. By entering Donbas he permanently alienated Ukrainians and enraged the Europeans. Sanctions have had a real impact because the Europeans have joined them, something Putin could have avoided had he been more skillful. This is like the pattern in the Cold War, where a better policy could have split the Europeans and the Americans, but the Soviets 
were never able to take advantage of this. This same can be attributed to Putin's policy on Ukraine and Syria. He has seriously undermined Russia's credibility, and this is essential for improving relations with Western Europe.

\section{Why is the wave of populism in Europe and the U.S. not decreasing?}

Nationalism and regional differences are a cultural reassertion of traditions and responses to economic hardships. Looking at the map of Germany, the Alternative for Germany gets support mostly in the eastern part of Germany. But this is not Western Europe versus Eastern Europe. The elites have not cared for neglected parts of society. We can observe such a situation with Brexit. In the case of the U.S. - President Trump's notorious norm breaking has surprised even skeptics and gave them cause to worry about the quality of his presidency. Claiming the election was stolen, telling faleshoods, stating that during impeachment hearings Congress was unable to legislate, which was a lie. When you look back, Nixon's and Clinton's impeachment hearings did not disrupt the passing of legislation. Refusing to allow anyone to testify provided evidence that Trump is undemocratic and undermining the people's faith in democracy and free media, undermining branches of the government.

If Trump is defeated next year would he go away quietly? After the second term, what would be the cost of it? American democracy is quite resilient. I think the next president would not follow the Trump model. Even if Trump has a second term, I think the Republican Party eventually will recover. I am not pessimistic, but do not have much evidence to support my hopes.

As most Americans, I am deeply worried about the events in Eastern and Central Europe, especially Hungary and Poland. The trends we see are strongly anti-democratic. Balance of power dynamics is necessary not only in international politics, it also works domestically. I optimistically predict that the forces of opposition, even if beaten down for a number of years, tend to come back, and the democratic institutions will prevail despite the current setback.

\section{Is the maximum pressure on Iran working? Does it prevent Iran from acquiring the nuclear bomb?}

Due to the maximum pressure - the answer is a little bit yes but basically no. It is doing damage to the Iranian economy, which is shrinking. Perhaps the current unrest will bring the regime down, although I doubt this. Europe has made a pragmatic calculation that it is very hard to oppose the U.S. I wish the EU would do more, but European business failed to pursue business in Iran because of their fear of losing access to American markets and financial arrangements.

In its policy to Iran, the American position is unclear and inconsistent. There is no vision or a real agenda for talks with Teheran. The countries with the burden of heavy sanctions have learnt how to live with limitations and can adjust to that situation. There is a similar situation with Iran. On the other hand, it is difficult to predict the moment of downfall. Trump believes that under heavy pressure Iran will finally agree to make concessions. Pompeo laid down the 12 steps which mean: surrender everything and we will talk. Trump probably will be happy with any face to face agreement. He says he will achieve a much better new JCPOA but really it is rather impossible. For him, it doesn't matter - especially while he is convinced that any deal he makes is the best ever. He got nothing from meeting Putin or Kim Jong Un. He really would like to sit down with Rouhani. The Iranian political situation cannot allow it. The American negotiating position is unclear and contradictory.

\section{Does Iran have the nuclear bomb?}

Iran is moving forward with its nuclear program, it seems that Iranians are doing this to gain the leverage with the EU, and I guess Tehran would not decide on the final stage of its nuclear program until the last minute. The initial Iranian plan to split the EU and the U.S. has failed because the Europeans are too vulnerable to American pressure. It would be just difficult to resume the 
JCPOA, due to its expiration date. A new Democratic administration will need to renegotiate a new JCPOA, and this will be a challenging task.

\section{Is globalization losing its momentum?}

In the 90s, Thomas Friedman wrote his book The Lexus and the Olive Tree. Now it is clear that we need globalization, but with people to matter in it. There are still many constraints on globalization, such as borders, distance, local economies and the local costs of transport. Maximum efficiency is not the only goal of globalization. The French economy is as productive as the American, or even more, if one measures its productivity and value per hour of work. While if one compares the GDP per capita, it is significantly lower because the French have more free time than Americans. Societies should have the right to decide. Another reason is that globalization at some point may decrease efficiency and can encourage monopolies and oligopolies. For example, each year the American consumer loses 5,000 dollars compared to a European consumer, because American antitrust enforcements are much more relaxed than in the EU. Economists are talking about the free flow of capital, goods and people. But the result can be worse when people are forced to move, in order to produce 1 per cent GDP more, which exposes the local communities to heavy pressure. Globalization should increase the American standard of life. Globalization constraints and challenges should be solved through the appropriate legislation for protecting society from the harmful outcomes of globalization.

\section{Robert Jervis is the Adlai E. Stevenson Professor of International Affairs at Columbia Uni- versity.}

He specializes in international politics in general, and security policy, decision making, and theories of conflict and cooperation in particular. His Why Intelligence Fails: Lessons from the Iranian Revolution and the Iraq War was published by Cornell University Press in April 2010. Among his earlier books are American Foreign Policy in a New Era (Routledge, 2005), System Effects: Complexity in Political and Social Life (Princeton, 1997); The Meaning of the Nuclear Revolution (Cornell, 1989); Perception and Misperception in International Politics (Princeton, 1976); and The Logic of Images in International Relations (Columbia, 1989). Jervis also is a coeditor of the Security Studies Series published by Cornell University Press. He serves on the board of nine scholarly journals and has authored over 100 publications.

Dr. Jervis is a fellow of the American Association for the Advancement of Science and the American Academy of Arts and Sciences. He has also served as the president of the American Political Science Association. In 1990 he received the Grawemeyer Award for his book The Meaning of the Nuclear Revolution. Dr. Jervis earned his BA from Oberlin College in 1962. He received his $\mathrm{PhD}$ from the University of California, Berkeley in 1968. From 1968 to 1974 he was appointed Assistant (1968-1972) and Associate (1972-1974) Professor of Government at Harvard University. From 1974 to 1980 he was Professor of Political Science at the University of California, Los Angeles.

Radoslaw FIEDLER ${ }^{2}$

2 Associate Professor - visiting scholar at Columbia University within Bekker Program of the National Agency for Academic Exchange (NAWA). 